\title{
WHY IS INTERCONTINENTAL CORRELATION WITHIN THE LOWER CAMBRIAN SO DIFFICULT?
}

\author{
Allison R. PALMER \\ Institute for Cambrian Studies. 445 N. Cedarbrook Rd. Boulder. Colorado. \\ 80304-0417. U.S.A. E-mail: palmera@spot.colorado.edu
}

\begin{abstract}
Palmer, A.R. 1998. Why is intercontinental correlation within the Lower Cambrian so difficult? liPor qué es tan difícil la correlación intercontinental en el Cámbrico Inferior?]. Revista Española de Paleontología, no extr. Homenaje al Prof. Gonzalo Vidal, 17-21. ISSN 0213-6937.
\end{abstract}

\begin{abstract}
Correlation of Lower Cambrian rocks is hampered because there are no widespread and rapidly evolving organisms such as the later agnostids, graptolites, conodonts, ammonites, or planktonic foraminifers, that might provide the basis for a consistent intercontinental biostratigraphy. Four problems illustrate the issue: 1) the age of the oldest trilobites of China; 2) acritarch correlations between Siberia and Baltica; 3) conflicts between archaeocyath and trilobite correlations; and 4) the location of the Lower Cambrian/Middle Cambrian boundary. There is no basis for an internationally useful set of Lower Cambrian stages at this time.
\end{abstract}

Key words: Lower Cambrian, intercontinental correlation, biostratigraphy, trilobites, archaeocyathids.

\section{RESUMEN}

La correlación en el Cámbrico Inferior se ve obstaculizada por la inexistencia de organismos ampliamente distribuidos en el espacio y de evolución rápida (como ocurre más tarde con los agnóstidos. graptolitos, conodontos, ammonites o foraminíferos), organismos que puedan proporcionar la base para una bioestratigrafía intercontinental coherente. Cuatro problemas ilustran la cuestión: 1) La edad de los trilobites más antiguos de China; 2) las correlaciones entre Siberia y Baltica con acritarcos: 3) algunos conflictos entre las correlaciones con arqueociatos y con trilobites; y 4) la posición del límite Cámbrico Inferior/Cámbrico Medio. Se concluye que no existe hoy la base suficiente para proponer una sucesión de pisos del Cámbrico Inferior que sea de utilización internacional.

Palabras clave: Cámbrico Inferior, correlación intercontinental, bioestratigrafía, trilobites, arqueociátidos.

Three principal problems hamper the effectiveness of correlation of Lower Cambrian rocks and faunas among the Cambrian continents. First, particularly for the trilobites, different environmental complexes have been sampled in different regions: Siberian, Australian, and Antarctic Lower Cambrian faunas are predominantly from carbonate regimes; Moroccan, Spanish, Chinese, Avalonian, and Baltic faunas are from predominantly siliciclastic regimes; and Laurentian faunas are mostly from inner shelf siliciclastics and shelf carbonates. This limits strict intercontinental comparability. Second, there were strong facies controls on the details of Cambrian associations within each of the major geographic regions, but evaluation of these controls for much of the world is still in its infancy. This is true for both macrofacies (such as inner shelf, restricted platform, ramp, reef belt, island arc, etc.) and microfacies (such as black or brown shale, platy limestone, bioclastic limestone, etc.). Finally, there really was a well-differentiated biogeography through much of Lower Cambrian time, because even comparable lithofacies on different Cambrian continents do not always contain comparable faunal elements; and palaeogeographies that reflect the macrofacies are not yet worked out for all areas. Further complicating matters is the possibility of a modest degree of nationalistic taxonomy, especially among the simple polymeroid trilobites, that obscures some interregional relationships.

Four correlation problems illustrate these issues as they are reflected in international correlation charts for Lower Cambrian rocks, mostly published in the past decade. The correlation discrepancies are a consequence of the fact that there are no widespread and rapidly evolving organisms in the Lower Cambrian comparable to the later agnostids, graptolites, conodonts, ammonites, or planktonic foraminifers, that might provide the basis for a consistent intercontinental biostratigraphy. Occasional genera, and (rarely) species, representing trilobites, archaeocyathans and other classes of Cambrian 


\begin{tabular}{|c|c|c|c|c|}
\hline \multicolumn{2}{|c|}{ SIBERIA } & $\begin{array}{c}\text { Repina } \\
1986\end{array}$ & $\begin{array}{c}\text { Zhuravlev } \\
1995\end{array}$ & $\begin{array}{c}\text { Landing } \\
1994\end{array}$ \\
\hline вот. & & & & $\operatorname{xxxxxxxx}$ \\
\hline \multirow{4}{*}{ ATD. } & Judomia & & $x x x x x x x x$ & \\
\hline & $\begin{array}{l}\text { Pagetiellus } \\
\text { anabarus }\end{array}$ & $x x x x x x x x$ & & \\
\hline & Fallotaspis & & & \\
\hline & Profallotaspis & & & \\
\hline TOM. & & & & \\
\hline
\end{tabular}

Figure 1. Comparative correlations of the oldest trilobitebearing beds of China $(x \times x \times x x)$ into Siberian Lower Cambrian trilobite biostratigraphy. TOM. $=$ Tommotian. ATD.$=$ Atdabanian. BOT $=$ Botoman.

fossils may be found in more than one region, but more often correlations depend on faunal similarities at the family level. Genera or species that do have some international distribution have such limited local stratigraphic ranges that in most cases their true biozones are only poorly known. An assumption that the occurrence of genus $(X)$, or even species $(X)$ in two different regions is evidence for precise correlation may be unjustified.

In the following examples, the Siberian stages will be used as a guide to compare various correlation schemes because almost all of the schemes in the past decade include correlations to these stages. Reasons why these stages are not really useful internationally, however, are discussed below.

The first serious problem involves opinions about correlation of the oldest trilobite-bearing beds of China (Fig. 1). Chinese problems with the age of the immediately pre-trilobite Meishucunian Stage, which was originally equated with the Tommotian Stage of Siberia, are well reviewed in Qian and Bengtson (1989). They concluded that the three distinct faunas of the Meishucunian are separated by important disconformities and that this "stage" ranges in age from Tommotian into the Atdabanian in Siberian terms. Landing (1994), based on study of small shelly faunas from the pre-trilobite beds of Avalonia, carried this even farther and presented a correlation chart on which the upper Meishucunian beds and the overlying oldest Chinese trilobite-bearing beds are no older than a level within the Botoman Stage. Zhuravlev (1995) took an intermediate position based on an observation that the species of Lapworthella in the youngest Meishucunian fauna is related to forms with earliest known occurrences in the later part of the Atdabanian. His correlation chart shows the oldest

\begin{tabular}{|l|l|l|l|l|l|}
\multicolumn{2}{c|}{ SIBERIA } & $\begin{array}{l}\text { Bidal et al. } \\
1995\end{array}$ & $\begin{array}{l}\text { Palmer and } \\
\text { Repina, 1997 }\end{array}$ & $\begin{array}{l}\text { Vidal et al } \\
1995\end{array}$ & $\begin{array}{l}\text { Palmer and } \\
\text { Repina, 1997 }\end{array}$ \\
\hline \multirow{4}{*}{ BOT. } & & & & & Olenellus \\
\hline \multirow{4}{*}{ ATD. } & Judomia & & Holmia & & \\
\cline { 2 - 6 } & $\begin{array}{l}\text { Pagetiellus } \\
\text { anabarus }\end{array}$ & & Schmidtiellus & & \\
\cline { 2 - 6 } & Fallotaspis & & & & Esmeraldina \\
\cline { 2 - 6 } & Profallotaspis & & & & Fallotaspis \\
\hline TOM. & & $\begin{array}{l}\text { Holmia } \\
\text { Schmidtiellus }\end{array}$ & & Olenellus & \\
\hline
\end{tabular}

Figure 2. Comparative correlations of trilobite zones for Baltica and Laurentia based on acritarchs (Vidal et al., 1995) and trilobites (Palmer and Repina, 1997). TOM.=Tommotian. ATD.=Atdabanian. BOT.$=$ Botoman.

trilobites of China to be no older than the middle part of the Judomia Zone at the top of the Atdabanian.

The conclusions of both Landing and Zhuravlev conflict with those of Repina (1986). She evaluated the Siberian and Chinese trilobite faunas and correlated the oldest Chinese trilobites to a level within the lower half of the Pagetiellus anabarus Zone in the middle of the Atdabanian Stage. Lower Cambrian correlations based on evaluations of different fossil groups clearly have significant discrepancies!

The second serious problem involves correlation of the Schmidtiellus mickwitzi and Holmia kjerulfi Zones of Baltica with Siberia and Laurentia (Fig. 2; Vidal et al., 1995). Acritarchs from supposed middle Tommotian beds in the Kharaulakh area near the mouth of the Lena River in Siberia represent an assemblage that correlates with the Vergale Horizon and its correlative, the Holmia kjerulfi Zone, on Baltica. On the basis of the acritarch determination, the authors equated the Holmia kjerulfi Zone/Vergale Horizon and the underlying Schmidtiellus mickwitzi Zone/ Talsy Horizon, as well as at least some of the Laurentian Bonnia-Olenellus Zone to the Tommotian! Such a correlation immediately gets the attention of trilobite workers for a number of reasons. Trilobite evidence from the Great Basin in Nevada and California raises extremely serious questions about the acritarch-based correlations. In one straightforward stratigraphic section near Tonopah, Nevada, basal beds of the Montenegro Member of the Campito Formation yield numerous individuals of Fallotaspis and Parafallotaspis (Hollingsworth, 1997). Higher in the Montenegro Member there are numerous horizons with various species of Esmeraldina which are clearly related to Holmia, but differ by having the third glabellar lobe unmodified distally. Distal expansion and modification of this lobe is characteristic of most Holmiidae and all true Olenellidae (Palmer and Repina, 1993) and is a derived character. The first true Olenellidae appear in the middle of the overlying Poleta Formation. Thus Esmeraldina is low in the evolutionary succession of the Olenelloidea, and Schmidtiellus, as well as Holmia, both of which have 
the modified third glabellar lobe, are evolutionarily younger than Esmeraldina and the still older fallotaspids. Because fallotaspids comprise the oldest trilobites in Morocco, Laurentia and Siberia, and characterize the lowest zones of the Atdabanian, something is clearly amiss with the acritarch correlations. Rozanov and Khomentovskiy (personal communications, 1995, 1996) both indicate that the collections reported in Vidal et al. (1995) might have come from the Pagetiellus anabarus level of the Atdabanian, which would make a little better sense. In any event, citation of Vidal et al. (1995) as evidence that trilobites existed in Tommotian times may perpetuate a serious mis-correlation.

A third problem involves the archaeocyathid and trilobite faunas of Antarctica and Australia. Debrenne and Kruse (1986) state that all of the archaeocyathan faunas from the Shackleton Limestone in the southern Churchill Mountains of Antarctica are of Botoman age. However, in situ collections of trilobites and associated archaeocyathans have been made from several localities in the same mountains that extend across the regional strike and overlap the area from which Debrenne and Kruse obtained their archaeocyathans. Two of the richest trilobite samples bear a fauna with species of Lemdadella and Yunnanocephalus that is clearly no younger than the Eoredlichia/Wutingaspis Zone at the top of the Chiungchussu Stage, the lowest trilobite-bearing Cambrian stage in China (Palmer and Rowell, 1995). This stage is considered to be late Atdabanian on the basis of trilobites by Repina (1986) and Jell (in Bengtson et al., 1990). Lemdadella is found in Morocco and Spain in the lower part of the Fallotaspis Zone, which is equated with the early Atdabanian. Another Antarctic collection contains species of Berabichia comparable to forms from Siberia and Morocco that characterize Atdabanian beds. The archaeocyathans directly associated with the trilobites have not been studied, so that a confirmation of conflict in correlations cannot be confirmed, but some caution is indicated regarding possible discrepancies between ages determined by trilobites and archaeocyathans, at least in the vicinity of the Atdabanian/Botoman boundary.

The difficulty of utilizing the Siberian stages outside of Siberia (and perhaps the Altay-Sayan foldbelt) is illustrated by evaluation of the Australian archaeocyathan faunas by Zhuravlev and Gravestock (1994). They conclude that the Jugalicyathus tardus archaeocyath zone, and perhaps the Abadiella huoi trilobite zone in South Australia span the Atdabanian/Botoman boundary (Fig. 3) - hardly a recommendation for recognition of this as a significant boundary in Australia! The A. huoi Zone, and the higher Pararaia tatei Zone, were considered to be upper Atdabanian equivalents by Jell (in Bengtson et al., 1990). Thus, there seem to be some conflicts involving correlations at the Atdabanian/ Botoman boundary between trilobites and archaeocyathans in Australia as well as Antarctica. These conflicts also highlight the impracticality, with present data, of a uniform stage nomenclature for the Lower Cambrian of the world.

\begin{tabular}{|c|c|c|c|}
\hline $\begin{array}{l}\text { Trilobite } \\
\text { Zones }\end{array}$ & $\begin{array}{c}\text { Archaeocyath } \\
\text { Zone }\end{array}$ & $\begin{array}{l}\text { Jell in Bengtson } \\
\text { et al., } 1990\end{array}$ & $\begin{array}{l}\text { Zhuravlev and } \\
\text { Gravestock, } 1994\end{array}$ \\
\hline $\begin{array}{l}\text { Pararaia } \\
\text { bunyerooensis }\end{array}$ & & \multirow{4}{*}{ 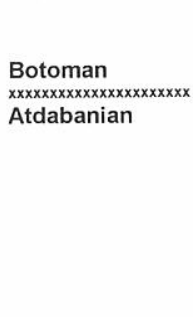 } & \multirow{4}{*}{ 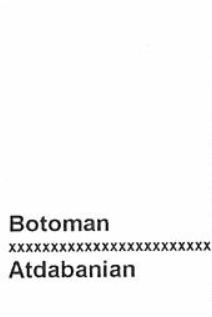 } \\
\hline Pararaia tatei & & & \\
\hline Abadiella huoi & \multirow[b]{2}{*}{$\begin{array}{l}\text { Jugalicyathus } \\
\text { tardus }\end{array}$} & & \\
\hline & & & \\
\hline
\end{tabular}

Figure 3. Comparative correlations to the Atdabanian/ Botoman boundary for South Australia based on trilobites and archaeocyaths.

A final and perhaps more serious problem involves Moroccan data that highlight conflicts in archaeocyathan and trilobite correlations between Morocco and Siberia, and in international positions for the Lower Cambrian/Middle Cambrian boundary (Fig. 4). The Sectigena Zone, at the top of the Banian Stage in Morocco yields various holmiids which seem to be medial Lower Cambrian in Laurentian terms and were roughly correlated with the Atdabanian by Palmer and Repina (1993). Later, Geyer and Palmer (1995) observed that the change from Antatlasiinae to Protoleninae at the Sectigena/Hupeolenus boundary is analogous to a similar change in faunas at the Atdabanian/Botoman boundary in Siberia. From the trilobite point of view, the base of the Hupeolenus Zone is near the base of the Botoman. In contrast, Zhuravlev (1995) and Debrenne and Debrenne (1995), from the archaeocyathan point of view, concluded that the family associations of archaeocyathans of the youngest Botoman Bergeroniaspis ornata Zone in Siberia suggest a correlation with the JebileticoscinusParanacyathus-Porocyathellus Zone, the youngest archaeocyath zone of Morocco, which is equivalent to the Sectigena trilobite zone. This places the overlying Hupeolenus Zone, in archaeocyathan terms, in the lower Toyonian, a full stage younger than the position based on trilobites! Some of the trilobite genera used to support the archaeocyathan correlations are eodiscids or other slopefacies genera whose local ranges may be much shorter than their true biozones and thus may not be very reliable for precise correlation. However, both the trilobite and archaeocyath correlations depend on family-level similarities and stages of evolutionary development - a pretty risky business.

Compounding the disagreement between correlations based largely on trilobites and those based on archaeocyathans, is the appearance of clearly identifiable species of Acadoparadoxides in the upper part of the Hupeolenus Zone, and an association of Acadoparadoxides with Cambropallas, an olenellid with apparent holmiid affinities, in the overlying Cephalopyge Zone. If the first appearance of Acadoparadoxides is taken as a definitive guide to the Middle Cambrian, then by roundabout correlations of Morocco with Laurentia, and Laurentia with Siberia, the Olenellus Zone seems to be 


\begin{tabular}{|c|c|c|c|}
\hline \multicolumn{2}{|c|}{ MOROCCO } & SIBERIA & LAURENTIA \\
\hline \multirow{3}{*}{ TISSAFINIAN } & $\begin{array}{l}\text { Ornamentaspis } \\
\text { frequens }\end{array}$ & \multirow{2}{*}{ 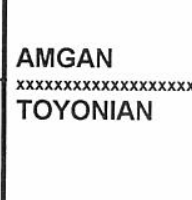 } & \multirow{4}{*}{ 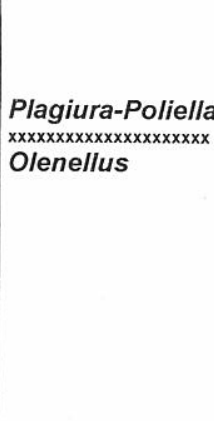 } \\
\hline & Cephalonvge & & \\
\hline & \multirow{2}{*}{ 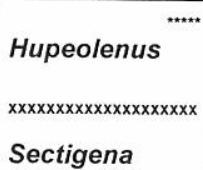 } & BOTOMAN & \\
\hline BANIAN & & ATDABANIAN & \\
\hline
\end{tabular}

Figure 4. Comparative positions for the Lower/Middle Cambrian boundary $(\mathrm{x} \times x \times x x)$. $* * * * *=0 l d e s t$ Paradoxides. (After Geyer and Palmer, 1995; Geyer, 1996.)

equivalent to Botoman and younger beds on the one hand, and the Acadoparadoxides-bearing beds of Morocco on the other (Geyer and Palmer, 1995). Thus there is a major international problem with criteria for determination of the boundary between the Lower and Middle Cambrian!

There are no quick solutions to most of the problems that have been discussed here. It seems clear that the stage boundaries of Siberia do not mark significant global events and thus their international usage tends to show only an illusion of precision in correlation. Furthermore, no one of the fossil groups used for correlation is independently identified as more reliable than any other one for correlation purposes, although each has its proponents. In addition, small shelly fossils within the trilobite-bearing part of the Lower Cambrian, which might aid international correlation, have not been uniformly searched for and studied. Trilobites, which are the most widespread of all groups, need to be analyzed in terms of the lithologies and depositional environments in which they occur so that the biostratigraphic reliability of such genera as Triangulaspis, Serrodiscus, Calodiscus, Atops, and Bathynotus which occur on more than one Lower Cambrian continent can be evaluated. Archaeocyathan assemblages need to be better integrated with the trilobite assemblages in China, Laurentia, and Antarctica, in particular, so that zonal boundaries involving both groups can be more clearly compared. Sharp faunal changes comparable to those between the Botoman and Toyonian stages in Siberia, and between the faunas at both the top and bottom of the Olenellus Zone on Laurentia need to be searched for in other Cambrian areas. These might reflect events that have intercontinental significance. Independent evidence from palaeomagnetism, geochronology, or isotopic excursions that might support the synchroneity of such events needs to be obtained.

So, why is international correlation of the Lower Cambrian so difficult? There were strong biogeographic differences within the Cambrian world; there are a number of areas where the key biostratigraphic details are as yet unstudied - Laurentia being one of the laggards in this regard; there is need for a much clearer picture of both large and small-scale facies controls on occurrences of Cambrian organisms; and perhaps some international short-courses in taxonomy of some of the key fossil groups would provide the opportunity for all workers to gain a shared level of understanding of the groups with which they work. The problems are not insurmountable, but current understanding suggests that we are low on the learning curve and not yet ready to fix into concrete an intercontinental scheme of correlation and any meaningful stage nomenclature. Field work involving careful biostratigraphic and lithostratigraphic analysis, noting all elements of the faunas, as well as development of stable schemes of taxonomy for most Lower Cambrian groups are a prerequisite for future progress.

The current state of understanding of Lower Cambrian biostratigraphy, taxonomy and correlation is reminiscent of the following famous poem about the blind men and the elephant.

It was six men of Indostan, to learning much inclined, who went to see the Elephant, (though all of them were blind), that each by observation might satisfy his mind.

The First approached the elephant, and happening to fall, against his broad and sturdy side, at once began to bawl: "God bless me, but the Elephant is very like a wall".

The second, feeling of the tusk cried: "Ho, what have we here, so very round and smooth and sharp? To me 'tis mighty clear, this wonder of an Elephant is very like a spear".

The third approached the animal, and happening to take the squirming trunk within his hands, thus boldly up and spake: "I see", quoth he, "the Elephant is very like a snake".

The fourth reached out his eager hand and fell about the knee. "What most this wondrous beast is like is mighty plain", quoth he. " 'Tis clear enough the Elephant is very like a tree".

The Fifth, who chanced to touch the ear, said: "E'en the blindest man, can tell what this resembles most. Deny the fact who can. This marvel of an Elephant is very like a fan".

The sixth no sooner had begun about the beast to grope, than, seizing on the swinging tail that fell within his scope: "I see", quoth he, "the Elephant is very like a rope".

And so, these men of Indostan disputed loud and long, each in his own opinion exceeding stiff and strong, though each was partly in the right, and all were in the wrong!

\section{REFERENCES}

Bengtson, S., Conway Morris, S., Cooper, B. J., Jell, P. A. and Runnegar, B. 1990. Early Cambrian fossils from South Australia. Association of Australasian Palaeontologists Memoir, 9, 1-364.

Debrenne, F. and Debrenne, M. 1995. Archaeocyaths of the Lower Cambrian of Morocco. In: Morocco '95. The 
Lower-Middle Cambrian standard of western Gondwana. Introduction, Field Guide, Abstracts, and Proceedings of the First Conference of the Lower Cambrian Stage Subdivision Working Group and I.G.C.P. Project 366 Ecological Aspects of the Cambrian Radiation. (Eds. G. Geyer and E. Landing). Beringeria, Special Issue 2, 121145.

Debrenne, F. and Kruse, P. 1986. Shackleton Limestone archaeocyaths. Alcheringa, 10, 235-278.

Geyer, G. 1996. The Moroccan fallotaspidid trilobites revisited. Beringeria, 18, 89-199.

Geyer, G. and Palmer, A.R. 1995. Neltneriidae and Holmiidae (Trilobita) from Morocco and the problem of Early Cambrian intercontinental correlation. Journal of Paleontology, 69, 459-474.

Hollingsworth, J. S. 1997. Cambrian trilobite extinctions, biomeres and stages. Mid-America Paleontology Society Digest, 20, 17-27.

Landing, E. 1994. Precambrian-Cambrian boundary global stratotype ratified and a new perspective of Cambrian time. Geology, 22, 179-182.

Palmer, A. R. and Repina, L. N. 1993. Through a glass darkly: taxonomy, phylogeny, and biostratigraphy of the Olenellina. The University of Kansas Paleontological Contributions, New Series, 3, 1-35.

Palmer, A. R. and Repina, L. N. 1997. Suborder Olenellina. In: Treatise on Invertebrate Paleontology. Part $O$. Arthropoda 1. Trilobita, Revised, Vol. 1: Introduction, Order Agnostida, Order Redlichiida. (Ed. R. L. Kaesler.) Geological Society of America and The University of Kansas, Boulder, Lawrence, 404-428.

Palmer, A. R. and Rowell, A. J. 1995. Early Cambrian Trilobites from the Shackleton Limestone of the Central
Transantarctic Mountains. The Paleontological Society Memoir, 45, 1-28.

Qian, Y. and Bengtson, S. 1989. Palaeontology and biostratigraphy of the Early Cambrian Meishucunian Stage in Yunnan Province, South China. Fossils and Strata, 24, 1-156.

Repina, L. N. 1986. Planetarnaja korreljatsija jarusnykh podrazdelenij nizhnego kembrija po trilobitam. [Global correlation of stage subdivisions of the Lower Cambrian according to trilobites.] In: Biostratigrafija i paleontologija kembrija Severnoj Azii. [Biostratigraphy and palaeontology of the Cambrian of northern Asia.] (Ed. I. T. Zhuravleva). Trudy Instituta geologii $i$ geofiziki, Sibirskoe otdelenie, Akademija nauk SSSR, 669, 4-25. [In Russian.]

Vidal, G., Moczydlowska, M. and Rudavskaya, V. R. 1995. Constraints on the early Cambrian radiation and correlation of the Tommotian and Nemakit-Daldynian regional stages of eastern Siberia. Journal of the Geological Society, 152, 499-510.

Zhuravlev, A. Yu. 1995. Preliminary suggestions on the global Early Cambrian Zonation. In: Morocco '95. The Lower-Middle Cambrian standard of western Gondwana. Introduction, Field Guide, Abstracts, and Proceedings of the First Conference of the Lower Cambrian Stage Subdivision Working Group and I.G.C.P. Project 366 Ecological Aspects of the Cambrian Radiation. (Eds. G. Geyer and E. Landing). Beringeria, Special Issue 2, 147160.

Zhuravlev, A. Yu. and Gravestock, D. I. 1994. Archaeocyaths from Yorke Peninsula, South Australia and archaeocyathan Early Cambrian zonation. Alcheringa, 18, 1-54. 